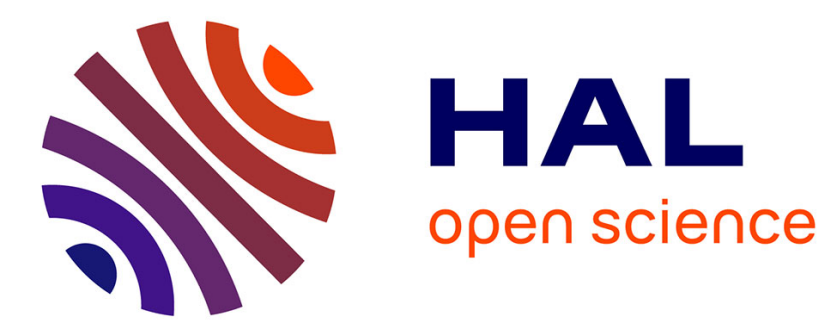

\title{
Explorative Studies in 16th century silver refining recipes
}

\author{
Joosje van Bennekom, Ellen van Bork, Florian Téreygeol
}

\section{To cite this version:}

Joosje van Bennekom, Ellen van Bork, Florian Téreygeol. Explorative Studies in 16th century silver refining recipes. Journal of Archaeological Science: Reports, 2021, 36, pp.102775. 10.1016/j.jasrep.2020.102775 . hal-03345436

\section{HAL Id: hal-03345436 https://hal.science/hal-03345436}

Submitted on 27 Sep 2021

HAL is a multi-disciplinary open access archive for the deposit and dissemination of scientific research documents, whether they are published or not. The documents may come from teaching and research institutions in France or abroad, or from public or private research centers.
L'archive ouverte pluridisciplinaire HAL, est destinée au dépôt et à la diffusion de documents scientifiques de niveau recherche, publiés ou non, émanant des établissements d'enseignement et de recherche français ou étrangers, des laboratoires publics ou privés. 


\title{
The Tricks of the Trade: Research into Adam Van Vianen's Silver Alloy
}

\author{
Joosje van Bennekom* \\ Rijksmuseum \\ Amsterdam \\ The Netherlands
}

j.van.bennekom@rijksmuseum.nl

\author{
Ellen van Bork \\ Rijksmuseum \\ Amsterdam \\ The Netherlands
}

e.van.bork@rijksmuseum.nl

\author{
Florian Thereygeol \\ French National Centre for \\ Scientific Research \\ Paris, France
}

$\underline{\text { florian.tereygeol@cea.fr }}$

*Author for correspondence

\begin{abstract}
When examining the alloy of several works of Adam van Vianen, who was one of the founders of the Dutch Kwabstijl, with X-ray fluorescence, a much higher silver and lower bismuth percentage and was found in the silver than was commonly used by his contemporaries. It is the hypothesis that Van Vianen used a high percentage of silver, as it is more malleable, and he could therefore obtain extreme deformation of the silver without the formation of cracks. Recipes on silver production and refinement in the silversmith workshop that would have been commonly used the time were selected to serve as a basis for making reconstructions in silver. These books were - the Probierbuchlein by Calbus of Freiberg and the Description of Leading Ore Processing and Mining Methods by Lazarus Ercker. Reconstructions were made, and the 'test' procedure, leading to 'blick' silver, generated highly refined silver, the silver being very malleable. It is therefore concluded that this recipe could have been used on purpose by Adam van Vianen to make his elaborate objects. On the other hand, there exists the possibility that this low bismuth content might be generated by coincidence, as a side effect to the multiple annealing and pickling cycles the objects went through.
\end{abstract}




\section{Introduction}

\section{$\underline{2.1 \mathrm{XRF} \text { measurements on Dutch silver }}$}

Currently the metals conservation studio at the Rijksmuseum is working on a database on the alloy of (Dutch) silver. ${ }^{1} \mathrm{X}$-ray fluorescence, calibrated with a silver standard set with many different ranges in impurities and recalculated by $\mathrm{PyMCA}^{2}$ is used the gain insight in the composition of silver from the middle ages onwards. The information gained could give information on when or where an object was made, and into workshop practice throughout history.

The silversmith Adam van Vianen and his brother Paulus are the founders of the Auricular style, known as the Kwabstijl in Dutch, which was developed in in the early $17^{\text {th }}$ century in the Netherlands. This unique style breaks with all former conventions in silver works of art, with organic contours in the shape of the silver, contrary to the classical symmetrical style of the Renaissance. It is said in literature and that Adam van Vianen used a different alloy than silversmiths that lived at the same time. ${ }^{3}$ The Kwab exhibition that was organized at the Rijksmuseum in 2018 gave the perfect opportunity to determine the alloy of several works made by Adam van Vianen, as many of his objects were on show (table 1). The results of the measurements showed that the silver percentage in these objects was much higher (97-98\%), and the bismuth content level lower (circa $0.02 \%)$, than what was the standard of assay office (resp. silver 93,5\%, bismuth roughly between $0.025-0.035 \%$ ) and is thus commonly found in silver $17^{\text {th }}$ century Dutch silver. ${ }^{4}$

\begin{tabular}{|l|l|l|l|l|l|l|l|}
\hline & $\mathrm{Ni}$ & $\mathrm{Cu}$ & $\mathrm{Zn}$ & $\mathrm{Ag}$ & $\mathrm{Au}$ & $\mathrm{Pb}$ & $\mathrm{Bi}$ \\
\hline $\begin{array}{l}\text { Adam van Vianen } \\
\text { (6 objects, } \mathrm{n}=\mathbf{4 0} \text { ) }\end{array}$ & $0.016+/-0.009$ & $1.776+/-1.194$ & 0 & $97.523+/-1.386$ & $0.187+/-0.113$ & $0.248+/-0.118$ & $0.015+/-0.001$ \\
\hline
\end{tabular}

Table 1: composition of the main components of six objects by Adam van Vianen, average

The following research questions arose from these findings:

1. What recipes on making the silver well workable and malleable could have been used by Dutch $17^{\text {th }}$ century silversmiths?

2. What kind of alloy composition do these recipes give, and is this composition similar to the one that Adam van Vianen used?

3. Would Adam van Vianen have used this alloy on purpose?

\footnotetext{
${ }^{1}$ This project is run by Joosje van Bennekom, head of the metals conservation department at the Rijksmuseum.

2 Olympus handheld Spectra; data were acquired with the next settings: $10 \mathrm{~mm}$ collimator, $30 \mathrm{sec}$ measurement tie, Ashmolean standards calibrated. PyMCA calibration file for silver was made by A. Pappot (PhD student Rijksmuseum) and A. Heginbotham (Getty Institute).

${ }^{3}$ See for example Louise E. van den Bergh-Hoogterp on silver from Adam van Vianens "Marcus Curtius" ewer, now in the Metropolitan Museum, New York (Stavelij, 1999, p.4-9). Artdealers Jacob Roosjens en Emiel en Esther Aardewerk also mentioned the different alloy composition to Joosje van Bennekom on different occasions.

${ }^{4}$ Data collected by Rijksmuseum, circa 120 objects form known provenance from the Netherlands. On request the database can be shown.
} 


\section{$\underline{2 \text { Recipes in treatises }}$}

\section{$\underline{2.2 .1 \text { Introduction }}$}

Two contemporary sources were consulted for recipes on silver processing and refinement; the Probierbuchlein by Calbus of Freiberg written in $1524^{5}$, and the Description of Leading Ore Processing and Mining Methods, from 1574 by Lazarus Ercker. ${ }^{6}$ It is likely that these books were known at the beginning of the $17^{\text {th }}$ century in Holland as they were written in German, a language that was understood by most of the Dutch. Also, the Probierbuchlein has a chapter on "How Assay Weights Are Made in the Netherlands", showing that there was interaction between Germany and Holland on silversmithing as early as the $16^{\text {th }}$ century. In both books recipes are given that describe the procedure for preparing silver in larger quantities for the workshop in detail.

Three recipes from the Probierbuchlein were selected; 'How a test should be made', 'How to Purify and Refine Silver for Graduation' and 'How to make silver malleable again' ${ }^{7}$. The titles of the recipes make them interesting even though they are not very detailed. The first and most elaborate recipe also appears in the book of Ercker, and gives a recipe how to prepare a large quantity of silver in the workshop. This recipe is the most important because it gives many practical details. The second recipe, with in its title the word 'graduation', should be interpreted as 'how to make silver pure so it can be used for alloying with copper to the required standards', which would give a very pure silver. The third recipe seems useful as Van Vianen used very pure and thus malleable silver, for his heavily worked objects. It indicates that there was a remedy for silver that was not very malleable, or when the silversmith wanted to deform the silver to a great extent. Although the recipe mentions 'making the silver malleable again', insinuating that it is intended for brittle or unworkable silver, which occurs when there is too much lead or other impurities in the silver, the recipe might have also been used to enhance the properties of already workable silver.

The main recipe in Ercker is, as said, similar to the Probierbuchlein's 'How a test should be made': 'How to refine silver, and how to make correctly the tests used in the process'. ${ }^{8}$ The recipe has many similarities with the one from the Probierbuchlein, although there are some variations, and Erckers recipes are more detailed. The scorifier for example, that is also used in Erckers recipe to refine the silver, is filled with woodash and topped with bone ash, instead of bone ash alone.

The fact that both books have a recipe for making this so called 'test' shows that this procedure was a common method used in silversmiths' workshops to refine larger quantities of silver. The method is similar to cupellation, the difference being that the cupellation method was used for small quantities, mainly for testing the silver by syndics of the guild. The 'test' is this same process but on a larger scale, a recipe which a silversmiths would have used very often, to refine their scrap metal that would contain solder, or impurities of other metals-, or to refine silver coins to make an object from. As a silversmith, the purity of the silver is very important. First, to avoid problems of other metals in your alloy, that could cause cracking and other unwanted reactions; secondly, to have almost a

\footnotetext{
${ }^{5}$ A.G. Sisco \& C.S. Smith „Calbus of Freiberg (and unknown authors), Bergbuchlein und Probierbuchlein, 1524, Lepizich" Yale University Press, New York, 1948.

${ }^{6}$ A.G. Sisco \& C.S. Smith “Lazarus Ercker, Description of Leading Ore Processing and Mining Methods, 1574, Prague" Chicago Press, Chicago, 1951.

${ }^{7}$ A.G. Sisco \& C.S. Smith, 1948, p.112 ev

${ }^{8}$ A.G. Sisco \& C.S. Smith, 1951. p.71
} 
hundred percent pure silver to start with to easily alloy it by adding copper to the silver to obtain the grade that was requested by the guild (commonly $92.5 \%$ silver, $7.5 \%$ copper).

The complete recipes are given in paragraphs 2.2.2 and 2.2.3.

\subsubsection{Calbus of Freiberg - Bergbuchlein und Probierbuchlein, 1524}

How a test should be made

"Take an iron ring, two or three fingers high, depending on how large a piece of silver you want to have, which, for up to fifteen marks ${ }^{9}$ [of silver], should be one span wide. Fill the ring with crushed bone ashes that shall have been passed through a fine sieve and shall be slightly moistened, and pound as hard as you can. Then hollow out the inside of the test to the shape that the piece of silver is to have. ...... When you have made the test as described, put it in the forge or between burnt brick, pile charcoal all around it, and leave the empty test two, three, or four hours in the fire to let it bake and become thoroughly aglow.

Next put it in fresh fire and put the silver right in it. Let it melt unassisted and when it starts to drive, remove the charcoal and dust from the test and with dry birch wood or a large piece of fir or birch charcoal build a bright fire on the test....let it continue to cupel until you see the little flames disappear and fade, and it blicks. If you extinguish [the fire] at this point and quench [the silver] you have crude silver.

If you [wait until] it becomes enveloped in clouds and darkness and then remove it from the fire and quench it, it is called fire-refined silver. And if it becomes back again and shines and looks beautiful, it is fine silver."

How to Purify and Refine Silver for Graduation

"Put it in a crucible and place this in front of the bellows. When the silver is molten, take finely crushed red ochre and throw it on the melt until it covers the silver by a finger's breadth; then leave it alone and stop the blast. After it has cooled, the silver will be purified. Do this one or three times and you will obtain the very purest silver possible, which can easily be graduated"

How to make silver malleable again

"Take crushed Venetian Glass and Venetian soap, and when the brittle silver drives [on a test], add the crushed glass and the soap gradually. The sulfur will then fume away and the [silver] become malleable'

\subsubsection{Lazarus Ercker - Description of Leading Ore Processing and Mining Methods, 1547}

How to refine silver, and how to make correctly the tests used in the process

"To refine silver in the fire means to purify and soften cupelled silver (which is still impure and not quite malleable) by firing it in a test. This is done in two ways: either under wood before the bellows, or under a muffle with nothing but charcoal.

\footnotetext{
${ }^{9} 1$ mark in Dutch weigh system of Trois pounds: circa 250 grams (see https://www.goudenzilverweging.nl/gsd tg, seen on $16 / 3 / 2020)$
} 
First I shall describe how the tests are made..." take wood ashed from which lye has been made and which are no longer biting..."Get an earthenware pan, unglazed... rinse it with water...then put in the pan a two finger thickness of the \{moistened\} ashes, gently stamp them down with a wooden tamper which should have eight prongs, then add more ashes, tamp them down too, and repeat this till the pan is full... The ashes next to the upper rim should be pressed down smoothly in the test with a turned wooden ball....hollow out the inside... When the test is hollowed out, take a hair sieve fill it with ground bone ash and dust the test therewith until it is very white".... \{then it is tested that the heat generated by the bellows is directly tunneled into the middle of the test\}

"Break the cupelled silver into small pieces; put a little straw in the test and the silver on top. Add burning coals and then charcoal until the silver and the test are completely covered, then work with the bellows and the silver will melt easily and start to drive."... "Then the charcoal is removed, and the pieces are covered with fir, spruce, pine or alderwood, the blast should hit the silver underneath and thus refine in the blast. What lead has been left after the first driving will go into the test".

\section{Experimental}

\subsection{Silver reconstructions/Reconstructions}

Reconstructions of the selected recipes were carried out in the open-air museum on the Carolingian silver mines of Melle as part of the Projet Collectif de Recherche called 'L'expérimentation paléométallurgique: de l'analogie à la modélisation'. ${ }^{10}$ The Rijksmuseum metals conservation studio has developed a so called 'historical alloy' which is a silver-copper alloy containing traces of bismuth, lead and zinc, which are commonly found in silver roughly from before 1875 . As X-ray fluorescence analyses showed that with the levels of these 'impurities' are a bit above what is found in $17^{\text {th }}$ century silver, this alloy was used for the experiment, as the bismuth level could be lowered by refining.

\begin{tabular}{|l|l|l|l|l|l|l|l|}
\hline & $\mathbf{N i}$ & $\mathrm{Cu}$ & $\mathrm{Zn}$ & $\mathrm{Ag}$ & $\mathrm{Au}$ & $\mathrm{Pb}$ & \\
\hline Silver before $(\mathbf{n}=\mathbf{1 5})$ & $0.011 \pm 0.007$ & $6.035 \pm 0.257$ & $0.018 \pm 0.007$ & $93.569 \pm 0.298$ & $0.104 \pm 0.003$ & $0.233 \pm 0.025$ & $0.053 \pm 0.002$ \\
\hline
\end{tabular}

Table 2: Historical developed silver alloy, average

Both recipes in the Probierbuchlein and Ercker do not explicitly mention the addition of lead for refinement. However, after a discussion with Dr. Florian Tereygeol, the project leader of the 'L'expérimentation paléométallurgique: de l'analogie à la modélisation', it became clear that the silver alloy could only be refined by adding lead, ${ }^{11}$ as this is essential in the refining process. It is unclear why this is not mentioned in the recipes. Possible the authors thought that it was common knowledge that lead is necessary for the refinement of silver, and it was therefore didn't mention it in their recipes. The amount of lead that needed to be added was calculated according to a scheme that was given in the 'Manuel d'Essayeur'12. Even though it is a later source, it seemed useful as the

\footnotetext{
${ }^{10}$ We were granted research time by Dr Florian Tereygeol, research director of the archeological department, French National Centre for Scientific Research (CNRS).

${ }^{11}$ Some silver that had to be refined would already be lead rich, because the product would come or 1) from lead mines where it would not have been necessary to add extra lead or from 2) the Saigerhutten process as by product from copper ores as leached out silver rich lead cakes. The recipes do not mention the addition of extra lead to the silver. Also for the refinement of silver of coins or scrap metal it would have been necessary to add extra lead. Maybe it was thought that the addition of lead is common knowledge in purification and cupellation of silver and it therefore wasn't explicitly mentioned in these recipes?

12 M. Vauquelin, 'Manuel d'Essayeur', Paris, Klostermann et fils, 1812, p.29. Table of d'Arcet, who calculated exactly how much lead was necessary to refine silver (per different amount of copper inside).
} 
process of refinement didn't change much until the second half of the $19^{\text {th }}$ century. For silver that contained $0.05 \%$ copper it was calculated that four times more lead than silver was necessary to remove the copper from the silver ${ }^{13}$. The following experiments were derived from the recipes. Four experiments were based on the main recipe with the 'test'. The test consists of an earthenware dish (scorifier), filled with bone ash, which is placed in the furnace, and heated until the silver melts (with or without lead) until it 'blicks'. This moment is well known among metallurgist or silversmiths and it is described in many metallurgical recipes. It describes an important visual moment in the oven, when the silver is molten, and is so hot it starts to roll around with lead oxides (litharge) floating on top of the molten silver. The blick moment occurs when the litharge -or impurities- is completely absorbed by the bone ash and the silver looks completely 'clear', like an orange dome. It is said that the word 'blick' derives from the Dutch 'bliksem' or German 'blitsen' (lightning), a sudden bright moment.

The four experiments varied in adding no lead or (extra) lead and heating time. The first two experiments were done in duplo. The recipe with a surplus of lead was added to overcome the possibility that the calculation in the 17th century might not have been so exact as the calculations we made based on a table from the $19^{\text {th }}$ century. The two last recipes were based on the red ochre and Venetian glass entries, and were only executed once. The red ochre experiment was set up in a crucible instead of a scorifier, to be able to mix the silver with the powder well without spoiling. The Venetian glass and soap were added in a scorifier with bone ash. The temperature was raised in this case, because soda-lime glass will melt only at high temperatures $\left(1000^{\circ} \mathrm{C}\right)$. During the time in the oven, we noted that the soap seemed to lower the melting point of the glass, because it melted very well. The potassium in the soap might have helped in lowering the melting point.

The tests were prepared by wetting sieved bone ash which was pressed into an earthenware scorifier. In the centre, some bone ash was removed to make a depression. Finally, the bone ash was compacted by hand, polished with an agate ball and left to dry overnight. The tests were carried out in a cupellation furnace big enough for the larger earthenware dish. An earthenware muffle was inserted, and charcoal of high quality was used to heat the furnace.

\footnotetext{
${ }^{13}$ If the silver was more contaminated ( $20 \%$ of impurities), it would have needed eleven times the weight in lead.
} 


\begin{tabular}{|c|c|c|c|c|}
\hline Recipe & Experiment & Material added & Time heating & ${ }^{0} \mathrm{C}$ \\
\hline \multirow{4}{*}{$\begin{array}{l}\text { "Test"procedure } \\
\text { from Probier- } \\
\text { buchlein and } \\
\text { Ercker }\end{array}$} & 1. Melting until blick & 16 gr. $\mathrm{Ag}-73 \mathrm{gr} \mathrm{Pb}$ & $+/-60 \min$. & $900-960$ \\
\hline & $\begin{array}{l}\text { 2.Melting beyond } \\
\text { blick }\end{array}$ & 16 gr. $\mathrm{Ag}-73 \mathrm{gr} \mathrm{Pb}$ & $+/-60 \min$. & $900-960$ \\
\hline & $\begin{array}{l}\text { 3.Melting until blick, } \\
\text { no lead added }\end{array}$ & 16 gr. Ag -0 gr Pb & $+/-60 \mathrm{~min}$. & $900-960$ \\
\hline & $\begin{array}{l}\text { 4.Melting until blick, } \\
\text { surplus lead added }\end{array}$ & 16 gr. $\mathrm{Ag}-93$ gr Pb & $+/-60 \mathrm{~min}$. & $900-960$ \\
\hline \multirow[t]{2}{*}{ Probierbuchlein } & $\begin{array}{l}5 . \text { Red ochre }{ }^{14} \text { (in } \\
\text { crucible) }\end{array}$ & $\begin{array}{l}16 \text { gr. Ag- Powdered } \\
\mathrm{Fe}_{2} \mathrm{O}_{3} \text {, enough to cover } \\
\text { the silver }\end{array}$ & 5-10 min. , $3 x$ & $900-960$ \\
\hline & $\begin{array}{l}\text { 6.Venetian glass and } \\
\text { soap }^{15} \text { (in scorifier) }\end{array}$ & $\begin{array}{l}16 \text { gr. Ag - } 16 \text { gr. glass } \\
\text { balls - } 3 \text { table spoons } \\
\text { soap }\end{array}$ & $30 \mathrm{~min}$. & 1000 \\
\hline
\end{tabular}

Table 3: Experiments done according to recipes from Probierbuchlein and Ercker

\subsection{Processing the silver}

The bullions that were produced during the experiments were separated from the tests and analysed with the XRF (see paragraph 4). They were sawn in half with a jeweller's saw, so one half could be used for further processing and the other half was kept as a reference. The halves were subsequently hammered, annealed and pickled ${ }^{16,17}$ six times, and again measured with the XRF, to determine difference in bismuth content after a normal working procedure for manufacturing object, and thus making them better comparable to the data from the Van Vianen objects. This procedure also gave insight into the malleability of the silver.

\section{Results}

\subsection{Silver melting experiments}

Experiments 1, 2 and 4 delivered a clean bullion, without any deposits left on the surface. Experiment 3 , without lead, resulted in an irregular bullion with a black surface. Experiment 5 gave a very interesting result. It seemed as if the glass had absorbed all the impurities from the melt: green, yellow and glossy grey spots appeared at the surface of the glass. These areas where measured with the ARTAX XRF ${ }^{18}$, and they appeared to be copper and zinc, but no lead was found. Experiment 6 gave a bullion with an irregular shape and holes through and through, with a greyish surface.

\footnotetext{
${ }^{14}$ Red ochre was prepared on the research site by filing a piece of red ochre stone near Rodez, France, from the collection of Dr. Florian Tereygeol.

${ }^{15}$ Venetian glass is a term that is not easily translated in a chemical composition. According to the glass conservator of the Rijksmuseum, Venetian glass was known to be of very pure quality (silica, chalk and sodium). We decided to use pure sodium chalk glass balls (https://www.laboratorium.shop/product/bohemia-glasparels-o-2-mm-massief-natronkalkglas-1$\mathrm{kgzak} / \mathrm{l}$ ). The Venetian soap probably was probably just of form of the common soft or lye soap still used nowadays, based on fatty acids cooked with lye. The one we used was bought via http://www.stukadoors-bouwstoffen.eu/saponevenezie.html (date 16/3/2020)

16 short H.A.P.

${ }_{17}$ van Laer, 1967, p.110. 1 I water, $6.8 \mathrm{gr}$ tartaric acid, 13,4 gr salt, heated in a copper container. NB During the tests it seemed as if the copper from the container was also dissolving slightly and reacted on the surface of the silver

${ }^{18}$ ARTAX XRF, collimator of $0.065 \mathrm{~mm}$, Molybdenum tube. Spectra program for analysis.
} 


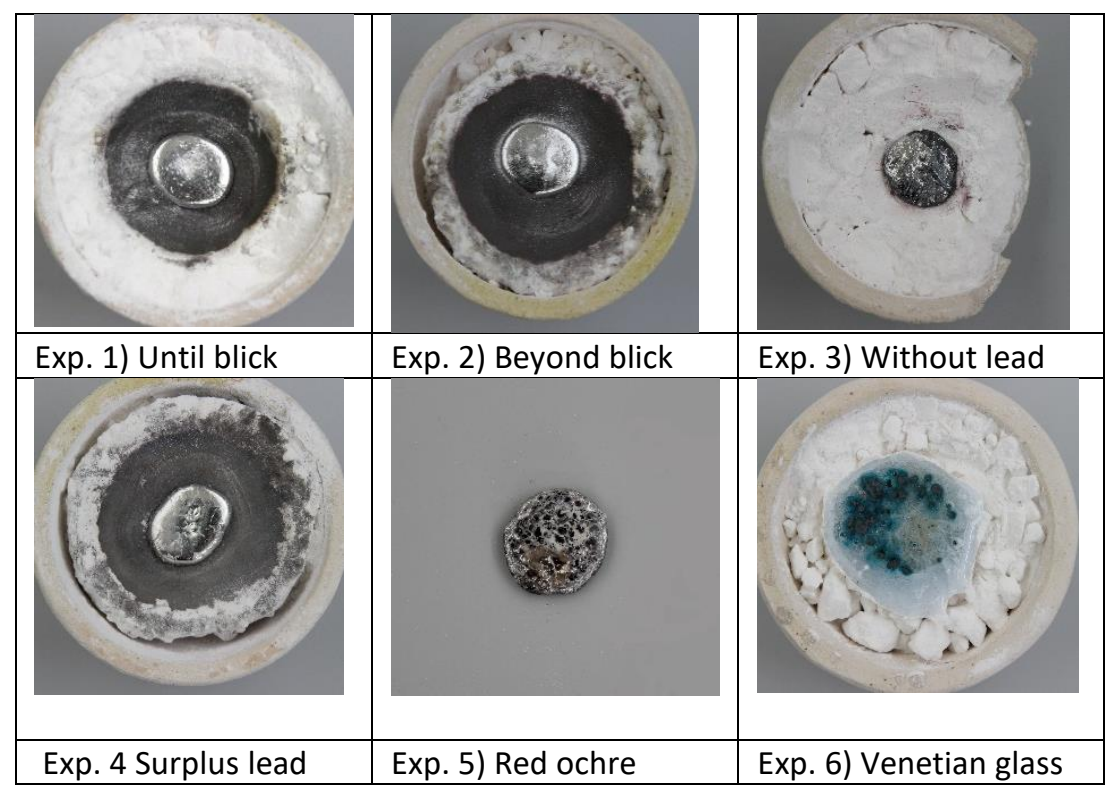

Table 4: casting results, bullion after cooling down in test or scorifier

The separated bullions were measured four times with the calibrated handheld XRF Olympus Delta. It is standard to analyse 16 elements in the alloy, however, only the most important elements, that show large differences, are presented below (table 5). The composition of the Rijksmuseum alloy, used for the experiments, is mentioned in the first row. The results of the experiments are stated in row 2-5. The Venetian glass experiment could not be measured at this stage, as it was still completely encapsulated by the glass.

\begin{tabular}{|l|l|l|l|l|l|l|l|}
\hline & $\mathrm{Ni}$ & $\mathrm{Cu}$ & $\mathrm{Zn}$ & $\mathrm{Ag}$ & $\mathrm{Au}$ & $\mathrm{Pb}$ & \\
\hline Silver before (n=15) & $0.011 \pm 0.007$ & $6.035 \pm 0.257$ & $0.018 \pm 0.007$ & $93.569 \pm 0.298$ & $0.104 \pm 0.003$ & $0.233 \pm 0.025$ & $0.053 \pm 0.002$ \\
\hline 1) Blick (n=4) & $0.034+/-0.003$ & $0.427+/-0.008$ & 0 & $99.439+/-0.045$ & $0.132+/-0.003$ & $0.01+/-0.004$ & $0.017+/-0.001$ \\
\hline 2) Beyond blick (n=4) & $0.019+/-0.005$ & $1.207+/-0.245$ & 0 & $98.396+/-0.321$ & $0.123+/-0.015$ & $0.266+/-0.105$ & $0.023+/-0.006$ \\
\hline 3) Without lead (n=1) & 0 & 77.566 & 0.723 & 21.082 & 0.006 & 0.606 & 0.11 \\
\hline 4) Surplus lead (n=2) & $0.026+/-0.004$ & $0.72+/-0.064$ & 0 & $99.019+/-0.162$ & $0.127+/-0.002$ & $0.075+/-0.015$ & $0.016+/-0.001$ \\
\hline 5) Red ochre (n=2) & $0.012+/-0.011$ & $8.843+/-5.264$ & $0.002+/-0.008$ & $90.961+/-5.203$ & $0.109+/-0.006$ & $0.01+/-0.001$ & $0.021+/-0.002$ \\
\hline 6) Venetian glass & n.m. & n.m. & n.m. & n.m. & n.m. & n.m. & n.m. \\
\hline
\end{tabular}

Table 5: XRF results of the bullion composition, average

Experiment 1, 2 and 4, have the highest silver content. Experiment 1 (until blick), has the lowest copper content and a very low bismuth and lead content. Experiment 2, (beyond blick), resulted in less pure silver, and thus proportionally more copper. Experiment 4, (excess of lead), resulted in pure silver, but with proportionally more lead and copper present in the alloy. The results from experiment 3 and 5 are not representative, because with experiment 3 a thick copper rich surface layer had formed on the silver, and with experiment 5 a black surface layer had formed, together with many holes in the bullion, which made the measuring difficult. 


\subsection{Processed silver}

The bullions could be placed in three categories in terms of their working properties: good, medium or bad malleability (table 6). The until 'blick' recipes (exp. 1) and the Venetian glass recipe (exp. 6) gave the best results, as no large cracks appeared during hammering, only some minor cracks along the edges. The beyond blick (exp. 2) and the red ochre (exp.5) recipes produced silver that started cracking after a few rounds of hammering, but was still relatively malleable. Exp. 3 and 4 gave silver that started cracking after one round of hammering.

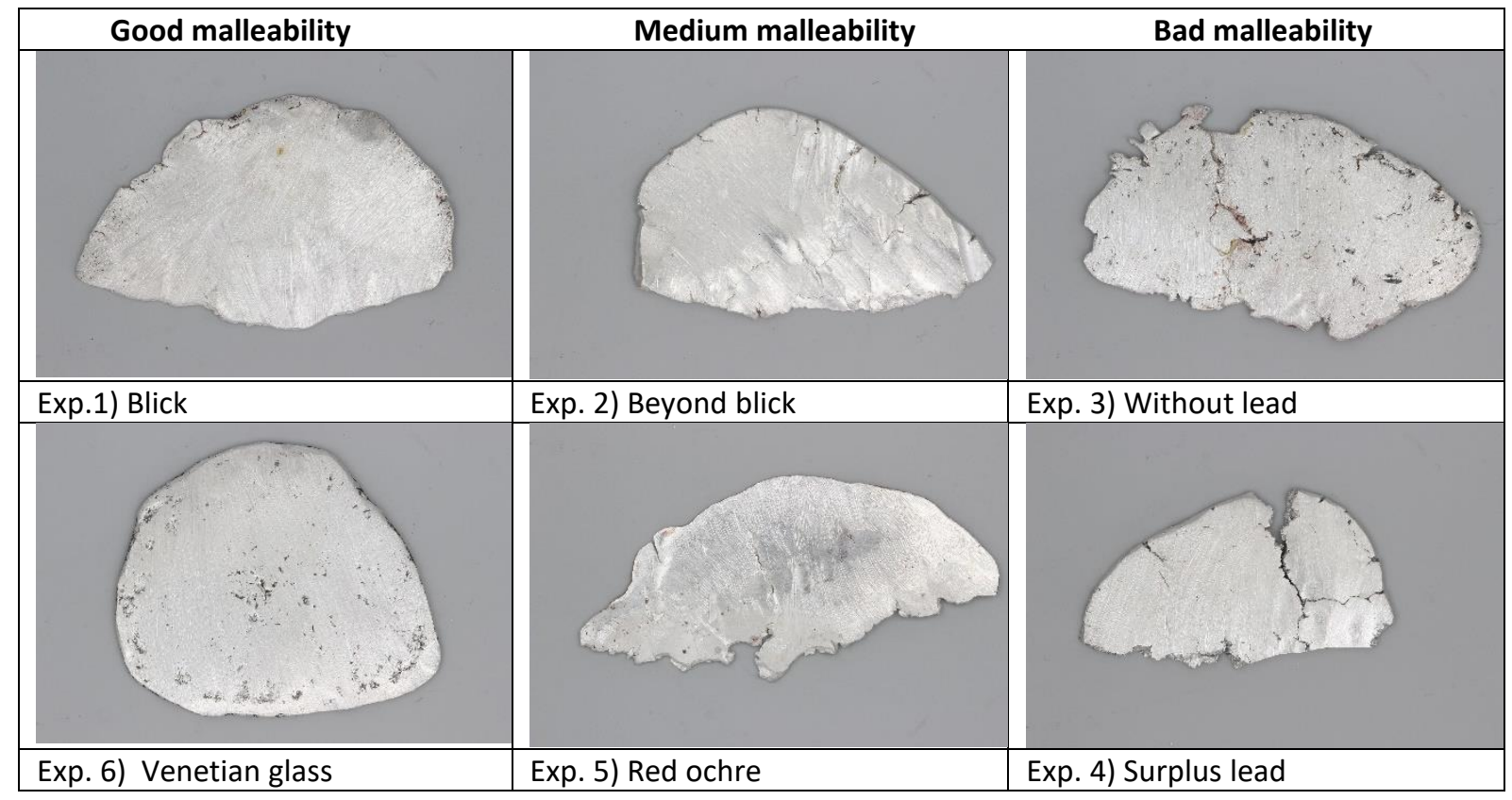

Table 6: Malleability results after hammering, annealing and pickling 
The results of the XRF measurements after the bullions were heated, annealed and pickled (after h.a.p.) can be seen in table 7 , and were compared with the initial results, directly after casting.

\begin{tabular}{|c|c|c|c|c|c|c|c|}
\hline & $\mathrm{Ni}$ & $\mathrm{Cu}$ & $\mathrm{Zn}$ & Ag & $\mathrm{Au}$ & $\mathbf{P b}$ & $\overline{B i}$ \\
\hline 1) Blick & $0.034+/ 0.003$ & $0.427+/ 0.008$ & 0 & $99.439+/-0.045$ & $0.132+/-0.003$ & $0.01+/-0.004$ & $0.017+/-0.001$ \\
\hline After h.a.p. $(n=8)$ & $0.025+/-0.007$ & $0.357+/-0.082$ & 0 & $99.333+/-0.189$ & $0.133+/-0.008$ & $0.109+/-0.131$ & $0.015+/-0.001$ \\
\hline 2) Beyond blick & $0.019+/-0.005$ & $1.207+/-0.245$ & 0 & $98.396+/-0.321$ & $0.123+/-0.015$ & $0.266+/-0.105$ & $0.023+/-0.006$ \\
\hline After h.a.p. $(n=8)$ & $0.021+/-0.005$ & $0.514+/-0.157$ & 0 & $99.211+/-0.224$ & $0.129+/-0.009$ & $0.122+/-0.123$ & $0.016+/-0.002$ \\
\hline 3) Without lead & 0 & 77.566 & 0.723 & 21.082 & 0.006 & 0.606 & 0.11 \\
\hline After h.a.p.(n=6) & $0.011+/-0.009$ & $4.216+/-1.597$ & 0 & $95.604+/-1.619$ & $0.123+/-0.002$ & $0.022+/-0.017$ & $0.02+/-0.004$ \\
\hline 4) Surplus lead & $0.026+/-0.004$ & $0.72+/-0.064$ & 0 & $99.019+/-0.162$ & $0.127+/-0.002$ & $0.075+/-0.015$ & $0.016+/-0.001$ \\
\hline After h.a.p. ( $n=2)$ & $0.027+/-0.002$ & $0.717+/-0.345$ & 0 & $98.875+/-0.525$ & $0.124+/-0.009$ & $0.258+/-0.217$ & $0.015+/-0.001$ \\
\hline 5) Red ochre & $0.012+/-0.011$ & $8.843+/-5.264$ & $0.002+/-0.008$ & $90.961+/ 5.203$ & $0.109+/-0.006$ & $0.01+/-0.001$ & $0.021+/-0.002$ \\
\hline After h.a.p. $(n=4)$ & $0.018+/-0.004$ & $2.349+/-0.282$ & 0 & $97.496+/-0.293$ & $0.126+/-0.003$ & $0.007+/-0.001$ & $0.018+/-0.001$ \\
\hline 6) Venetian glass & n.m. & n.m & n.m. & n.m. & n.m. & n.m. & n.m. \\
\hline After h.a.p.(n=4) & $0.017+/-0.001$ & $3.088+/-0.812$ & $0.011+/-0.01$ & $96.693+/-0.868$ & $0.127+/-0.007$ & $0.026+/-0.012$ & $0.018+/-0.004$ \\
\hline
\end{tabular}

Tabel 7: In white the bullion composition after hammering, annealing and pickling $6 \mathrm{x}$, average mean,

For nickel and lead there is no consistency in increase or decrease after the h.a.p. treatment in the silver alloys. Copper diminishes largely, what was expected, as the pickling is a step in silversmithing necessary to remove the copper oxides from the surface, prohibiting these oxides from being incorporated in the surface of the silver during hammering. The silver, zinc and bismuth content diminished less drastically, but are leached out of the surface. The only element that decreases in almost all cases is gold, which is as expected, it will not react with the sulfuric acid.

\section{Discussion}

\subsection{Malleability of the silver}

Experiments 3 (without lead) and 4 (surplus of lead) have bad malleability and already started cracking during the first round of hammering. Their composition is quite different: experiment 3 has $4,2 \% \mathrm{Cu}$ and 95,6\% $\mathrm{Ag}$ where experiment 4 has 0,7\% $\mathrm{Cu}$ and 98,9\% Ag after HAP. The Pb en Bi levels, however, are very similar.

The 'test' procedures and the Venetian glass recipe all gave malleable silver. These recipes contain a low copper percentage and a high silver percentage. The lead percentage falls in between 0.2 and 0.3 $\%$. Lead is known to embrittle silver. ${ }^{19}$ However, the silver measured for the Dutch silver database in the $17^{\text {th }}$ century usually contains in between 0.25 and $0.35 \%$ lead, which could therefore be considered as a workable percentage, not causing immediate cracks in the silver. The cracking in our

\footnotetext{
${ }_{19}$ Wanhill, R.J.H., Archaeological silver embrittlement: a metallurgical inquiry, National Aerospace Laboratory NRL, The Netherlands, 2002, p.12
} 
tests hence cannot be explained by of the presence of lead, as this is in the same range or even lower.

The blick 'without lead', red ochre and Venetians glass experiment contain a very low lead percentage and show medium to severe cracking, or, in the case of Venetian glass no cracking. This could indicate that a high or low percentage of lead does not influence the malleability of the silver. ${ }^{20}$

Considering the accurateness of the recipes, whether they deliver workable silver, one can say that the 'test' blick recipe delivers good material, and well cleaned from all impurities, therefore a good starting material for alloying. Both the red ochre and Venetian glass experiment, the last one promising, did not deliver a pure silver alloy, although the trace elements copper, lead and bismuth did diminish. It is known from other research that glass was used as a refinement method for gold; it would be interesting to try this recipe again with different settings. ${ }^{21}$

A remarkable fact to note here is that both recipes do not mention the adding of lead to purify the silver, but the experiments showed that our silver needed lead to get purified. Why then, do the recipes do not explicitly mention lead? The Probierbuchlein does not mention it at all, and the recipe in Ercker mentions lead almost in passing at the end of its recipe: "What lead has been left after the first driving will go into the test", which makes this an important sentence. Could it be that the 'test' procedure was the step after the first -larger scale -refinement (that took place near the mines)? The Saigerhütten process was one of the most used methods to produce silver: copper ore (containing small amount of silver) was roasted with lead on fires, and the molten lead would extract the silver from the copper cakes. The copper could be worked further, and the lead rich silver needed to be purified from the lead on a large scale in a hearth..$^{22}$ Because of this large scale, it is well possible that a lot of lead was still inside the silver after this first purification. It seems likely that the 'test' procedure is used as the successive step. It also seems plausible that silversmiths knew of these differences in use, and knew that with contaminated silver without extra lead they had to add extra lead themselves. Some other recipes in Ercker, to be investigated at a later stage, do mention the addition of lead, for example when melting coins for reuse.

\subsection{Silver recipes compared to Adam van Vianen's silver}

The main question was whether the recipes to prepare silver or to make it more malleable that were known in the time of Adam van Vianen, could result in an alloy that was similar to the alloy $17^{\text {th }}$ century used for his extremely raised and worked objects.

From the recipes that were tested, two of them refine the silver in such a way that the alloying elements are almost in the same ratio as the Adam van Vianen silver, as can be seen in table. 8 . The bismuth content in Vianen's silver is very similar to the 'blick' and 'beyond blick' experiments. The lead content is a bit higher in Adam van Vianen's silver. The copper content in Vianen's silver though

\footnotetext{
${ }^{20}$ Possibly, a combination of trace elements causes cracking, for example a too high sum of bismuth, lead and nickel. When these elements are summed up for the samples that gave malleability and the ones that started cracking, no significant differences are found between the malleable and cracking silver. It should also be taken into account that the shape of a halve bullion is odd, as the thickness varies a lot from the center to the edges, which can cause additional stress to the material when hammering, and thus cause cracking. A silversmith would have cast the silver into a barre or sheet of an even thickness, which would diminish the stress in de material during hammering. However, the bullions can be intercompared as they roughly have the same shape.

${ }^{21}$ Rehren, Th., Nixon, S. Refining gold with glass- an early Islamic technology at Tadmekka in Journal of Archaeological Science 49(2014) 33-41.

${ }^{22}$ See M.P. Guirado, F. Tereygeol \& F. Peyrat 'Initial experiments on silver refining: How did a cupellation furnace work in the $16^{\text {th }}$ century" in Historical Metallurgy, no 44, part 2, 2010 (126-135), were the refinement of silver on a larger scale in a furnace, based on descriptions by Agricola is researched.
} 
is clearly higher. An explanation could be that the silver was otherwise too soft and therefore vulnerable, hence Van Vianen added a small amount of copper to make the blick silver sturdier and more resilient.

\begin{tabular}{|l|l|l|l|l|l|l|l|}
\hline & $\mathrm{Ni}$ & $\mathrm{Cu}$ & $\mathrm{Zn}$ & $\mathrm{Ag}$ & $\mathrm{Au}$ & $\mathrm{Pb}$ & $\mathrm{Bi}$ \\
\hline $\begin{array}{l}\text { Adam van Vianen } \\
\text { (6 objects, } \mathrm{n}=\mathbf{4 0} \text { ) }\end{array}$ & $0.016+/-0.009$ & $1.776+/-1.194$ & 0 & $97.523+/-1.386$ & $0.187+/-0.113$ & $0.248+/-0.118$ & $0.015+/-0.001$ \\
\hline $\begin{array}{l}\text { Beyond blick and } \\
\text { h.a.p. (n=8) }\end{array}$ & $0.021+/-0.005$ & $0.514+/-0.157$ & 0 & $99.211+/ 0.224$ & $0.129+/-0.009$ & $0.122+/-0.123$ & $0.016+/-0.002$ \\
\hline Blick and h.a.p. (n=8) & $0.025+/-0.007$ & $0.357+/-0.082$ & 0 & $99.333+/ 0.189$ & $0.133+/-0.008$ & $0.109+/-0.131$ & $0.015+/-0.001$ \\
\hline
\end{tabular}

Table 8: 'Blick' and 'beyond blick refinement compared to Adam van Vianen silver.

However, there exists another possibility that would deliver an alloy with very low trace elements in the silversmiths' workshop, by coincidence. Earlier experiments that were done where a silver samples were heated and pickled 20 times without hammering, showed no decrease in de bismuth level. ${ }^{23}$ This current research does, however, show a slight decrease of bismuth after HAP. It is therefore possible that the hammering of the silver has an influence on the trace elements that are dissolved by the acid treatment. By hammering the silver, the surface enlarges and therefor trace elements that were hidden in the bulk, are exposed and subsequently dissolved in the pickle. It should be taken into account that for the earlier experiments vitriol was used and for the current research tartaric acid was used. As the pieces of Van Vianen were most likely heated and pickled numerous times, due to the extreme deformation and decoration of the silver, it is plausible that the repeated hammering and pickling did have an influence on the alloy composition and the amount of trace elements. When the silversmith starts with a silver alloy alloyed in the common way with $7.5 \%$ copper (as requested by the guild) it could be possible, when the object is very elaborate and has gone through many HAP cycles, that the trace elements dissolve, and thus diminish. The typical alloy from Adam van Vianen would then not be an conscious choice, but a coincidence, caused by the multiple cycles of hammering annealing, and pickling of the objects.

\section{Conclusion}

The questions that were posed in the introduction can only be partly answered.

1. What recipes on making the silver workable and malleable could have been used by Dutch $17^{\text {th }}$ century silversmiths?

The two books that were probably wide spread and well known in the Netherlands, which contain several recipes to deliver workable silver, were used for this research. The 'test' procedures 'until blick' delivered a silver alloywith a high silver content and a good malleability.

The Venetian glass and red ochre experiments though, did not result in an alloy with a high silver content, which did not seem to affect the malleability of silver from the Venetian glass experiment. On the contrary, it did deliver a workable piece of silver. The glass had extracted impurities and incorporate these elements in its matrix.

\footnotetext{
${ }^{23}$ Experiments were done at the Rijksmuseum metals conservation studio in 2019. The samples were heated with a torch until they were cherry red. They were subsequently cooled in water and pickled in $10 \%$ sulfuric acid in water solution for ca. 2 minutes
} 
2. What kind of alloy composition do these recipes give, and is this composition similar to the one that Adam van Vianen used?

The 'until blick' recipesilver alloys with a high silver content and a good malleability, and could therefore be considered similar to that of Adam van Vianen. The Venetian glass experiment though, did not result in an alloy with a high silver content, but this did not seem to matter for the malleability of this silver. The silver from the other experiments differed from Van Vianen's alloy either in terms of alloy or malleability.

\section{Would Adam van Vianen have used this alloy deliberately?}

Until now Adam van Vianen's elaborate objects are the only objects in the Dutch silver database that show such a low percentage of bismuth. It is likely that Adam van Vianen was aware that the silver of the 'test' procedure ('blick silver') was of the highest purity possible at that time, and that this silver was very malleable. Because Adam van Vianens was one of the most appraised silversmiths of his time, it is also possible that he could afford it to invest in high quality silver.

However, the fact that de bismuth levels also dropped slightly after HAP could be another explanation for the low bismuth levels Van Vianen's work. In future, when other very heavily worked objects that can be compared to the works of van Vianen are added to the database, the bismuth percentage should be compared to the content of Adam Van Vianen's, to see whether they show the same effect.

\section{Future research}

We hope this project will be followed up by more research into the workshop receipts from the Probierbuchlein and Lazarus Erckers book. Besides that, there are some questions after the research presented here should be addressed:

1) Where does the bismuth come from: from the original silver ores (copper or lead ores), or is it added later when the silver is alloyed with copper? The objects from Adam's contemporaries show a higher bismuth content. But these silversmiths would also have worked with refined -and hence bismuth free- silver (970 and higher), graduating it afterwards with copper to $935 \%$ silver. In what phase of the making of an object does the bismuth introduced.

2) Another question is: when the unrefined silver contains different amounts of bismuth per batch, do they end up with all the same low bismuth content after the 'test' procedure or does this vary?

3) Finally, new coupons with a high bismuth content should be treated according to the HAP procedure, to determine how much the bismuth percentage diminishes. 